\title{
Correction to: Clustering analysis of tumor metabolic networks
}

\author{
Ichcha Manipur ${ }^{1}$, Ilaria Granata', Lucia Maddalena ${ }^{1}$ and Mario R. Guarracino $1,2^{*}$
}

\section{The original article can be found online at https://doi org/10.1186/s12859-020-} 03564-9.

\section{${ }^{*}$ Correspondence:}

mario.guarracino@cnr.it

${ }^{1}$ Institute

for High-Performance

Computing and Networking

National Research Council,

Via P. Castellino 111,

80131 Naples, Italy

Full list of author information

is available at the end of the article

\section{Correction to: BMC Bioinformatics 2020, 21(Suppl 10):349 https://doi.org/10.1186/s12859-020-03564-9}

Following publication of the original article [1], the authors identified that all the figures in additional file 7 and additional file 8 were missing.

The complete and correct Additional file 7 and Additional file 8 are included in the Supplementary information section of this correction.

\section{Supplementary information}

Supplementary information accompanies this paper at https://doi.org/10.1186/s12859-020-03840-8.

Additional file 7. t-SNE-based visual representations. The file AdditionalFile7.pdf provides the t-SNE visual representations for expression, whole graph, and summarized graph data in Breast Microarray, Breast RNAseq, and Lung datasets

Additional file 8. Heatmap representations. The file AdditionalFile8.pdf provides the heatmap representations for summarized graphs in Breast Microarray, Breast RNAseq, and Lung datasets.

\section{Author details}

${ }^{1}$ Institute for High-Performance Computing and Networking, National Research Council, Via P. Castellino 111

80131 Naples, Italy. ${ }^{2}$ HSE - National Research University Higher School of Economics, LATNA Laboratory, 13 Rodionova Ulitsa, Nizhny Novgorod, Russia.

Published online: 02 November 2020

Publisher's Note

Springer Nature remains neutral with regard to jurisdictional claims in published maps and institutional affiliations.

(c) The Author(s) 2020. Open Access This article is licensed under a Creative Commons Attribution 4.0 International License, which permits use, sharing, adaptation, distribution and reproduction in any medium or format, as long as you give appropriate credit to the original author(s) and the source, provide a link to the Creative Commons licence, and indicate if changes were made. The images or other third party material in this article are included in the article's Creative Commons licence, unless indicated otherwise in a credit line to the material. If material is not included in the article's Creative Commons licence and your intended use is not permitted by statutory regulation or exceeds the permitted use, you will need to obtain permission directly from the copyright holder. To view a copy of this licence, visit http:// creativecommons.org/licenses/by/4.0/. The Creative Commons Public Domain Dedication waiver (http://creativecommons.org/publi cdomain/zero/1.0/) applies to the data made available in this article, unless otherwise stated in a credit line to the data. 